pronounce those of the Pitury as derived from bis $D u$ boisic Hoprwoodiz, described in $186 \mathrm{r}$ (Fragnn. Phytogr. Austr. Il., 138). This busin extends from the Darling River and Barcoo to West Australia, through desert scrubs, but is of exceedingly sparse occurrence anywhere. In fixing the origin of the Pitury, a wide field for further incuiry is opened up, inasmuch as a second species of Duboisia (D. myoporoides, R. Br.) extends in forest land from near Sydney to near Cape York, and is traced also to New Caledonia, and lately by him also to New Guinea. In all probability this $D$. myoporoicles shares the properties of $D$. Hopwoodiz; as he finds that both have the same burning acrid taste. Baron Mueller adds: "Though the first known species is so near to us, we never suspected any such extraordinary properties in it as are now established for the later discovered species. Moreover, the numerous species of the allied genus Anthocercis, extending over the greater part of the Australian continent and to Tasmania, should now also be tasted, and further the many likewise cognate Schrenkeas of South America, should be drawn into the same cyclus of research, nothing whatever of the properties of any of these plants being known. The natives of Central Australia chew the leaves of Duboisia Hoprwoodiz, just as the Peruvians and Chilians masticate the leaves of the Coca (Erythroxylon Coca), to invigorate themselves during their long foot journeys through the deserts. I am not certain whether the Aborigines of all districts in which the Pitury grows are really aware of its stimulating power. Those living near the Barcoo travel many days' journeys to obtain this, to them, precious foliage, which is carried always about by them brokeir into small fragments and tied up in little bags. It is not improbable that a new and perhaps important medicinal plant is thus gained. The blacks use the Duboisia to excite their courage in warfare, a large dose infuriates them."

\section{THE ANTIQUITY OF MAN}

O $\mathrm{N}$ Tuesday evening last a conference was held at the rooms of the Anthropological Institute on the Present State of the Question of the Antiquity of Man. The chair was taken by the president, Mr. John Evans, F.R.S. There were also present Lord Talbot de Malahide, Prof. Huxley, Prof. Prestwich, Prof. Rolleston, Prof. Busk, Prof. Boyd Dawkins, Prof. McK. Hughes, Rev. Prof. Say'ce, Mr. J. Heywood, Col. Lane Fox, Mr. A. W. Marks, Capt. Douglas Galton, Rev. E. W. Edgell, and many other gentlemen.

The President in opening the conference alluded to the altered position of the question since it was first brought before the British public in 1859, and pointed out the extreme caution which was necessary in dealing with the subject as it lay within the domain of the archeologist, the anthropologist, and the geologist, neither of whom alone was sufficient by himself to offer a very strong opinion on the subject. Great care was also necessary with $r$ egard to the facts of the discoveries themselves, as the objects discovered were liable to get mixed with other objects below them, and this was important in the case of cave deposits in which there might be interments of a later date than the human skeletons deposited in the caves. The question was now very much within the province of the geologist, whose business it was to determine the antiquity of the deposits in which the discoveries may have been made. After alluding to several recent discoveries in France, Spain, and Switzerland, the President remarked that each successive discovery or presumed discovery must be received in a cautious but candid spirit, and looking to the many sources of doubt and error which attached to isolated discoveries, their watchword must for the present be "caution, caution, caution."

The debate was opened by Prof. Boyd Dawkins by an inquiry into the value of the evidence offered by the bonecaves of Great Britain. The antiquity of man is not to be measured by the system of chronology used by the his. torian, but by the physical and biological changes familiar to the geologist. Beyond historical record time past cannot be estimated in terms of years, because of our ignorance of the length of the intervals, and of the time necessary to produce the changes which mark the hour on the geological dial, The caves of Cresswell Crags, recently brought before the Geological Society, were taken as types, showing the strange association of human implements and remains of animals. Bones and teeth of species now found only in the south, such as the spotted hyma and lion, were lying side by side with those of northern habit, such as the reindeer, while some are extinct, such as the mammoth and woolly rhinoceros, and others, such as the stag, horse, and bison, still live in the temperate regions. This mixed fauna is universal in British bone-caves, and in those of France and Germany, and it cannot be accounted for by the supposition of Messrs. James Geikie and Croll that the southern animals inhabited Britain in a warm period inter-glacial, while the northern were here at another time after, with an interval between them of from 5,000 to 12,000 years; not only because they are closely associated together in the same strata, but because we have full proof that northern and southern species coexisted at the same time on the same place, in the fact that the reindeer formed an important portion of the prey of the hyæna. It may, however, be accounted for by the overlapping of faunas according to the ever-varying summer heat and winter cold over what was then a vast continent, extending from Northern Africa as far as the 10o-fathom Iine off the coast of Scotland and Scandinavia. The palreolithic man of the caves belongs to the northern group of the pleistocene animals, and his remains are therefore of late pleistocene age. This northern group invaded Europe as the glacial cold came on, was pushed down as far south as the Mediterranean, the Alps, and Pyrenees, as the ice-sheet advanced southwards, and on its retreat passed again northwards. It therefore follows that they are both pre- and post-glacial in Britain. Some caves have been inbabited by man in post-glacial times, as, for example, that of Pont Newydd, near St. Asaph, but it does not follow that all palreolithic caves are post-glacial. The Victoria Cave offers no evidence as to the antiquity of man, because fibula found in association with the pleistocene inammalia, and supposed to be human, is most probably ursine. Further the relation of the deposit in which it was found to the glacial strata of the district is a matter of dispute.

The facts brought forward by Mr. James Geikie, that all palæolithic remains are of earlier date than post-glacial times may be interpreted otherwise. The "something like perpetual summer" which he considers necessary for the presence of the southern animals in the mixed fauna of the caves and of which there is no trace in post-glacial times, is inconsistent with the abundance of reindeer invariably associated with the palæolithic remains of the caves. The barren areas in Great Britain, in which no pleistocene species are found, may be reasonably accounted for by the fact that they were covered with ice, zvhile the species were living in more glaciated regions in the south, than by the view that they were equally distributed over the whole area, and afterwards removed by ice for the glaciated regions. The glacial phenomena are no guide to age in non-glaciated districts. In fine, the evidence of the caves is decisive that these palæolithic inhabitants are of late pleistocene age, post-glacial, and possibly pre-glacial, and glacial.

Prof. Hughes, after a few remarks on some foreign cases in which man had been referred to periods more remote than was generally included under the term glacial, commenced by explaining that in using the word glacial he meant the period in which conditions prevailed in the area in question such as must have caused glacier ice, or in adjoining areas which, by supplying berg or coast ice or influencing the climate, must have affected the area in question. He then proceeded to criticise the cases adduced from the neighbourhood of Brandon and Thetford. By an appeal to sections he showed that the beds in which the flint implements had been found were remains of valley deposits resting on older deposits which he referred to the middle glacial.

He explained the varfous divisions of the middle glacial beds and correlated them with deposits of the same age in Hertfordshire, pointing out that there were several horizons at which loams occurred. He then showed that the beds in which the flint implements had been found rested upon various members of the middle glacial series and occurred in troughs and hollows scooped out of the middle glacial beds. In the case of the 
Jeeches Pit, opposite Culford, he said that the implements were found in a deposit which seemed to he the end of a terrace of valley gravel which, further down as it was followed towards Icklingham, became more clearly marked, consisting of gravel and brick-earth with pupa, pisidium, and mammalian remains.

The only deposits at all like boulder clay which either in the Bceches Pit or at Botany Bay overlaid these implement-bearing loams, he corsidered to be the wash either from boulder clay or directly from the chalk as the case might be.

Mr. R. H. Tiddeman then read "Some Observations on the Fyeena Bed at the Victoria Cave, and its Bearing on the Antiquity of Man." After some remarks on the disputed fibula formerly determined to be human, which had been found at a great depth in the cave deposits in the hyrena bed, the author went on to call attention to two bones, one certainly of goat, and another a rib of a small ruminant probably belonging to the same species, on both of which are cuts or hacks which appear to be the result of human workmanship. These were also found in the same bed at the depths respectively of 25 and 15 feet. In considering the age of these it was remarked that the condition of a bone is not necessarily a test of age, and in many instances might be a most fallacious guide. It was admitted that the goat has not been usually considered as introduced into Britain before Neolithic times, but it certainly had appeared in the Victoria Cave in association with the remains of hyrena, Elephas anciquizs, Rhunoceros leptorhinus, and Hippopotamus. In the caverns in the neighbourhood of Dinant-sur-Meuse, in Belgium, M. E. Dupont records the goat as occurring in the lower beds in the same association. It seems, therefore, not improbable that it should have occurred in Britain at the same time.

If these are human work manship, as appears probable, this cave holds only in common with other caves, the works of man so accompanied, and the actual finding of man or his works in the cave is a secondary question compared to the correlation of the beds with certain great and widespread physical changes.

The hyæna bed contains amongst others besides hyæna, the following-Elephas antiquies, Rhinoceros leptortinus, and Hip. popotamus. These were chosen as a well-maried fauna, about which no doubt was entertained that they were contemporary. They occur in non-gravels in France and Switzerland and in the south and east of England, and in each of these countries are associated with man's bones or handiwork. The geologists who have worked chiefly at the drifts of the south of England main. tain, and rightly, that these remains are then post-glacial ; but to infer that they are so in the north of England may lead to error. Their remains appear to have been removed from the open country there by glaciation, although from their existence in the Victoria Cave and another near Skipton they must at one time have been as abundant in the valleys as they are in the south. The author considered that this later glaciation was on the wane during its maximum at about the parallel of Derbyshire, and it appeared probable from authorities quoted that it had not extended over the southern end of the Pennine Chain. The glacial drifts further south and of earlier age than the animals referred to appeared to be the relics of an earlier glaciation than that of the north country, and extended further south. The author believed that the acceptance of two great and wellmarked periods of glaciation differing. in their extent would reconcile many of the differences which now exist amongst geologists as to the age of man and the drifts of this and other countries.

An interesting discussion followed, of which we hope to be able to give some account next week.

\section{OUR ASTRONOMICAL COLUMN}

The Revolving Double Stars.-Dr. Doberck, of Col. Cooper's Observatory, Markree, has published elements of $\xi$ Bootis, calculated from measures extending over ninety-five years, which interval appears to be about two-thirds of a com. plete revolution. In this second computation for the same star he has followed a suggestion made in this column (NATURE, vol. xiv. p. 475), with regard to the probable interpretation of Sir William Herschel's measures in 1792 and I795, and his results prove the necessity for the alteration proposed.

We are now indebted to Dr. Doberck for orbits of thirteen of the revolving double stars, calculated in every case in the most complete manner possible from the available data, and which have been communicated from time to time to the Royal Irish Academy. They form collectively a very valuable contribution to this department of astronumy. Col. Cooper may be congratulated on such work emanating from his observatory, and Dr. Doberck likewise on the success which has attended his efforts. We subjoin the periods and eccentricities for Dr. Doberck's stars, omitting only $\zeta$ Aquarii, which from the great length of period is open to more uncertainty than the others :--

\begin{tabular}{|c|c|c|c|c|c|}
\hline & & & $\begin{array}{l}\text { Period. } \\
\text { Years. }\end{array}$ & & Eccentricit \\
\hline$\gamma$ Corona Borealis & $\ldots$ & $\cdots$ & $95 \cdot 5$ & $\ldots$ & 0.350 \\
\hline$\xi$ Scorpii & $\ldots$ & $\ldots$ & $95 \%$ & $\ldots$ & 0.077 \\
\hline$\omega$ Leonis & $\ldots$ & .. & 110.8 & $\ldots$ & 0.536 \\
\hline$\xi$ Bootis & $\ldots$ & $\cdots$ & $127^{\circ} 4$ & $\ldots$ & 0.708 \\
\hline$\tau$ Ophinchi ... & $\ldots$ & $\cdots$ & $185 \cdot 2$ & $\ldots$ & 0.582 \\
\hline$\eta$ Cassiopere & $\ldots$ & $\ldots$ & 2224 & $\cdots$ & 0.576 \\
\hline$\lambda$ Ophiuchi ... & $\ldots$ & $\ldots$ & $241^{\circ} 0$ & $\cdots$ & 0.493 \\
\hline 44 Bootis ... & $\ldots$ & $\ldots$ & $26 I \cdot i$ & $\ldots$ & 0.710 \\
\hline$\mu^{2}$ Bootis $\ldots$ & $\ldots$ & $\ldots$ & $290 \cdot 1$ & $\ldots$ & 0.617 \\
\hline 36 Andromecise & $\ldots$ & ... & $349^{\prime} I$ & $\ldots$ & 0.054 \\
\hline$\gamma$ Leonis $\quad .$. & $\ldots$ & $\cdots$ & 4026 & ... & 0.739 \\
\hline o Corona Borealis. & & $\cdots$ & $843^{\circ} 2$ & $\ldots$ & 0.750 \\
\hline
\end{tabular}

The number of binary stars of which the orbits have been determined by various calculators with a greater or less degree of precision, now amounts to twenty-five. The shortest period of revolution hitherto detected belongs to 42 Comze Berenices, which, according to M. Dubiago, of Pulkowa, in a communication from M. Otto Struve to the St. Petersburg Academy in May 1875 , amounts to only $25^{\circ} 7$ I years. The star was single in 1845 and $1870-7 \mathrm{r}$; in 1829 and $1854-55$ the distance of the components slightly exceeded six-tenths of a second, which is the greatest separation. The iraclination of the orbit to the tangent-plane of the heavens is $90^{\circ}$, or so nearly so that the measures appear to be represented upon this assumption within their possible errors; thus the apparent orbit is a right line, with the direction $\mathrm{II}^{\circ}-\mathrm{I} 9 \mathrm{I}^{\circ}$. Notwithstanding the difficulty of the case, $\mathrm{M}$. Dubiago has been able to assign the other elements of the orbit with a fair degree of probability as follows :-peri-astron passage $1859^{\prime} 92$, angle between the peri-astron and the node, $99^{\circ}{ }^{\prime} 1^{\prime}$, eccentricity $0^{\circ} 480$, semi-axis major $0^{\prime \prime} \cdot 657$. The distance of the components at the present time will therelore be $0^{\prime \prime} 50$, with the smaller star on an angle of $\mathbf{I}^{\circ}$.

From the elements of $\xi$ Bootis by Dr. Doberck, to which reference is made above, the following appear to be the angles and distances, up to about the epoch of the approaching periastron passage, 1898.04 :-

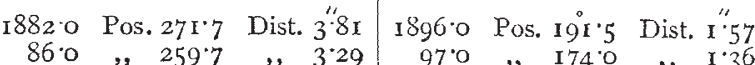



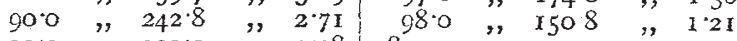

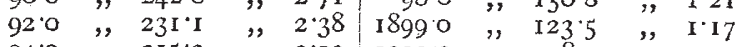

$$
\begin{aligned}
& 94^{\circ} 0 . ", 215^{\circ} 3 \text { ", 200 1900 " } 98.2 \text { " }
\end{aligned}
$$

Physical Observations of Mars.-Mr. Marth has communicated to the Royal Astronomical Society an elaborate paper intended to facilitate physical observations of the planet Mars during the favourable opposition of the present year, when it is much to be desired that observations tending to improve our knowledge of the planet may be undertaken by those who are provided with adequate instruments. Mr. Marth has calculated the areographical longitude and latitude of the centre of the disc for the times of about ninety sketches of Mars, by Dawes, von Franzenau, Harkness, Kaiser, Lassell, Lockyer, Rosse, and Secchi, and with the aid of a table applicable to the interval June 9-December 14, with very little trouble the observer will be enabled to refer to the particular drawing. which applies the most nearly to the time of any proposed observation, and will thereby be assisted in fixing upon the details of the surface to which it may be desirable to direct his attention. The table contains the angle of position of the axis of Mars, no doubt from Bessel's elements, or rather trose deduced by Oudemanns from 